\title{
Radical nephrectomy for large renal tumors: evaluate perioperative and oncological outcomes of stage T2a and T2b
}

\section{Büyük renal kitlelerde radikal nefrektomi: $T 2 a$ ve $T 2 b$ renal tümörlerde perioperatif ve onkolojik sonuçların değerlendirilmesi}

\author{
Taha Numan Yıkılmaz ${ }^{1}$, Erdem Öztürk ${ }^{1}$, Halil Başar ${ }^{1}$ \\ ${ }^{1}$ Dr. Abdurrahman Yurtaslan Ankara Onkoloji Eğitim Ve Araştırma Hastanesi Üroloji Kliniği, Ankara
}

Dergiye Ulaşma Tarihi: 11.04.2017 Dergiye Kabul Tarihi: 04.05.2017Doi: 10.5505/aot.2017.21932

\begin{abstract}
ÖZET
Giriş: Yedi $\mathrm{cm}$ ve üzerindeki renal malignitelerde açık radikal nefrektominin perioperatif ve onkolojik sonuçlarının değerlendirilmesi amaçlanmıştır.

Materyal ve Metod: Haziran 2010 ile Ocak 2015 tarihleri arasında T2 klinik evre $(>7 \mathrm{~cm})$ ile açık radikal nefrektomi yapılan 36 olgu retrospektif olarak değerlendirildi. Operasyon sonrası nihai patolojileri onkositom, anjiyomyolipom ve ksanto granülamatöz piyelonefrit gelen 5 olgu çalışma dışı bırakıldı. Olgular klinik evrelerine göre 2 gruba ayrıldı: T2a $(7-10 \mathrm{~cm})$ ve T2b $(<10 \mathrm{~cm})$. Olguların demografik özellikleri, tümörün karakteristik özellikleri, perioperatif ve onkolojik sonuçlar kayıt edilerek karşılaşıtırıldı.

Bulgular: Çalı̧̧maya alınan 31 olgunun 23 tanesinin (\%71) klinik evresi T2a, 8'inin ise (\%29) T2b. Tümör boyutu $10 \mathrm{~cm}$ altında bulunan 23 olgunun 8 tanesinde (\%34), T2b tümörlerde ise 4 olguda (\%50) patolojik evre artmıştır. Olguların \%61'inde klinik ve patolojik evre korele bulunmuştur. Toplam 9 olguda (\%29) rekürrens gelişmiş bunların 5 tanesi (\%16) lokal nüks, 4 tanesi ise (\%13) uzak metastaz şeklindedir. Uzak metastazların 2 tanesi akciğere birer tanesi ise kemik ve beyine olmuştur.

Sonuç: Rekürrens ile papiller histolojik varyantın, yüksek Fuhrman derecesinin, vasküler tutulumun ve perinefritik yayılımın ilişkili olduğu gözlenmiştir. Klinik T2b varlığının rekürrens ihtimalini artırdığı ancak tek başına rekürrensle ilişkisi olmadığı gösterilmiştir.
\end{abstract}

Anahtar Kelimeler: Renal hücreli karsinom, radikal nefrektomi, onkolojik sonuçlar

\begin{abstract}
Objective: We aimed analyzing the perioperative and oncological outcomes of $>7 \mathrm{~cm}$ renal tumors treated with open radical nephrectomy.

Material and Methods: We retrospectively reviewed records of 36 cases undergoing open radical nephrectomy due to T2 clinical stage $(>7 \mathrm{~cm}$ ) between June 2010 and October 2015. Five cases were excluded which have pathology with oncocytoma, angiomyolipoma and ksantha granulamatousis pyelonephritis. The cases were divided into 2 groups: T2a $(7-10 \mathrm{~cm})$ and T2b $(<10 \mathrm{~cm})$. The cases demographics, tumor characteristics, perioperative and oncological outcomes were compared.

Results: Of the 31 cases, 23 (71\%) had tumors stage T2a and 8 (29\%) had tumors clinical stage T2b. The tumor stage was more often up staged 8 cases (34\%) in 23 patients at $<10 \mathrm{~cm}, 4$ cases $(50 \%)$ in 8 patients at $>10 \mathrm{~cm}$. The clinical stage correlated with the pathologic size in $61 \%$ of the patients. A total of 9 cases (29\%) developed recurrence, including $5(16 \%)$ with local and $4(13 \%)$ with distant recurrence. The sites of distant recurrence included lung in 2, brain in 1 and bone in 1 case.

Conclusion: The significant predictors of recurrence were papillar histological variant, high Fuhrman grade, renal vein invasion and perinephric extension. Stage T2b increased recurrence risk but not alone.
\end{abstract}

Key Words: Renal cell carsinoma, radical nephrectomy, oncological outcomes

\section{Giriş}

Böbrek hücreli kanser (BHK) tüm kanserlerin \%2-3'ünü oluşturmaktayken ürolojik tümörler arasında en sik görülen 3. kanser türüdür. Özellikle 6. ve 7. dekatta ve erkeklerde daha s1k izlenmektedir $(1,2)$. Tümörün etyolojisinde sigara kullanımı, obezite ve antihipertansif 
tedavi alımı sayılmaktadır (2). Hastalar sıklıkla asemptomatik iken hematüri, yan ağrisı veya paraneoplastik semptomlar ile de başvurabilmektedir. Farklı nedenlerle yapılan radyolojik tetkikler sirasinda tanı konulan olguların çokluğu nedeniyle insidental tümör olarak da adlandırılmaktadır 3. Böbrek hücreli kanserlerde tümör boyutu önemli bir prognostik faktördür ve tedavinin şeklini belirlemektedir bu nedenle evreleme sistemi kritik öneme sahiptir 4. Böbrek tümöründe 2009 y1lında belirlenen TNM evrelemesi halen kullanılmakta ve boyutlarına göre evrelendirildiğinde T1a 4 $\mathrm{cm}$ ve alt1, T1b $4 \mathrm{~cm}$ ile $7 \mathrm{~cm}$ arasinda $(7 \mathrm{~cm}$ dahil), T2a $7 \mathrm{~cm}$ ile $10 \mathrm{~cm}$ arasinda $(10 \mathrm{~cm}$ dahil), T2b ise $10 \mathrm{~cm}$ üzerindeki kitlelerdir (5). Radyolojik tetkiklerin gelişimi ile beraber küçük renal kitlelerin tanısı kolaylaşmaktayken cerrahideki tecrübenin artmasiyla da büyük kitlelere yaklaşımda daha az invazif yöntemler kullanılabilmektedir. İlk açık radikal nefrektomi 1869 'da G. Simon tarafindan ilk açık parsiyel nefrektomi ise 1884 y1lında Wells tarafindan uygulanmıştır. İlk laparoskopik radikal nefrektomi tecrübesi ise Clayman ve ark tarafindan 1991'de rapor edilmiștir (6-8). Avrupa Üroloji Birliği kılavuzlarında $4 \mathrm{~cm}$ altındaki (T1a) tümörlerde parsiyel nefrektomi, $4 \mathrm{~cm}$ ile $7 \mathrm{~cm}$ arsındaki (Tlb) tümörlerde laparoskopik radikal nefrektomi, $7 \mathrm{~cm}$ üzerindeki kitlelerde ise açık radikal nefrektomi önerilmektedir (5). $\mathrm{Bu}$ çalışmada $7 \mathrm{~cm}$ üzerindeki T2a ve T2b olguların perioperatif ve onkolojik sonuçları analiz edilmiştir.

\section{Materyal ve Metod}

Kliniğimizde Haziran 2010 ile Ocak 2015 tarihleri arasında T2 klinik evre $(>7 \mathrm{~cm})$ ile açık radikal nefrektomi yapılan 36 olgu çalışmaya alındı. Olguların birine açık parsiyel nefrektomi yapılmış ancak ilk patolojik bulgularda cerrahi sınır pozitifliği gelmesi üzerine açık radikal nefrektomiye geçilmiștir. Operasyon sonrası nihai patolojileri onkositom, anjiyomyolipom ve ksanto granülamatöz piyelonefrit gelen 5 olgu çalışma dışı bırakıldı. Preoperatif dönemde tüm olgulara aksiyel planda kontrastlı bilgisayarl1 tomografi (BT) veya manyetik rezonans görüntüleme (MRG) yapıldı. Olgular klinik evrelerine göre 2 gruba ayrıldı: T2a (7-10 $\mathrm{cm})$ ve $\mathrm{T} 2 \mathrm{~b}(<10 \mathrm{~cm})$. Olguların demografik Tablo 1. Hasta ve tümör özellikleri özellikleri, tümörün karakteristik özellikleri, perioperatif ve onkolojik sonuçlar kayıt edilerek karşılaştırıldı. Çalışma retrospektif olarak gerçekleştirildi. Hasta sayısı yeterli olmamasindan dolayı istatistiksel analiz yapilamadi.

\section{Bulgular}

Çalışmaya alınan 31 olgunun 23 tanesinin (\%71) klinik evresi T1a, 8'inin ise (\%29) T2b. Her iki grubun da yaş ortalaması benzer bulunurken, T2b olguların tümü erkek cinsiyetten oluşmakta idi. Grup 1 yani klinik T2a olguların tümör boyutu ortalaması $86,1 \mathrm{~mm}$ iken grup 2'nin ortalamas1 119,6 mm olarak hesaplanmıştır. Grup 1 olguların tümör patolojilerinde yoğun bir şekilde berrak hücreli kanser patolojisi görülmekte iken (\%87), grup 2 de bu oran $\% 50$ şeklindedir. Klinik evre ile patolojik evrelerin karşılaştırılmasında tümör boyutu $10 \mathrm{~cm}$ altında bulunan 23 olgunun 8 tanesinde (\%34) patolojik evrelerinde artış gözlenmiştir. $\mathrm{Bu}$ olguların 5 tanesinde (\%21) perinefritik invazyon, 3 tanesinde ise (\%13) renal ven invazyonu görülmüştür. Klinik $\mathrm{T} 2 \mathrm{~b}$ tümörlerde ise 4 olguda (\%50) patolojik evre artmıştır. Olguların 2'sinde (\%25) perinefritik invazyon, 2 tanesinde ise $(\% 25)$ vasküler tutulum görülmüștür. Olguların \%61'inde klinik ve patolojik evre korele bulunmuştur. Hastaların demografik özellikleri ve tümör karakteristik özellikleri Tablo 1'de açıklanmıştır. Onkolojik sonuçlar değerlendirildiğinde grup 1'deki olguların 4 tanesinde $(\% 17,3)$ rekürens görülürken grup 2 de bu say1 5 olgu $(\% 62,5)$ şeklindedir. Toplam 9 olguda (\%29) rekürrens gelişmiş bunların 5 tanesi $(\% 16)$ lokal nüks, 4 tanesi ise $(\% 13)$ uzak metastaz şeklindedir. Uzak metastazların 2 tanesi akciğere birer tanesi ise kemik ve beyine olmuştur. Rekürens gelişen olguların 4 tanesi Fuhrman grade 3, 5 tanesi ise Fuhrman grade 4 özelliktedir. Her iki gruptan da papiller varyanta sahip olguların tümünde rekürrens gözlenmiştir. Diğer parametrelerin de değerlendirilmesiyle rekürrens ile papiller histolojik varyantın, yüksek Fuhrman derecesinin, vasküler tutulumun ve perinefritik yayılımın ilişkili olduğu gözlenmiştir. Klinik T2b varlığının rekürrens ihtimalini artırdığı ancak tek başına rekürrensle ilişkisi olmadığı gösterilmiştir. 


\begin{tabular}{|c|c|c|c|}
\hline & \multicolumn{2}{|c|}{ Klinik evre } & \multirow[b]{2}{*}{ Total } \\
\hline & $\mathrm{T} 2 \mathrm{a}$ & $\mathrm{T} 2 \mathrm{~b}$ & \\
\hline Hasta sayısı & $23(\% 71)$ & $8(\% 29)$ & $31(\% 100)$ \\
\hline Yaş & 58,6 (37-71 yaş) & 56,5 (36-60 yaş) & $53,2(36-71)$ \\
\hline Cinsiyet (E/K) & $16 / 7$ & $8 / 0$ & $24 / 7$ \\
\hline Tümör boyutu & $86,1(71-95 \mathrm{~mm})$ & $119,6(103-150 \mathrm{~mm})$ & \\
\hline Lateralite (Sağ/Sol) & $13 / 10$ & $2 / 6$ & $15 / 16$ \\
\hline \multicolumn{4}{|l|}{ Histolojik alt tip } \\
\hline Şeffaf hücreli tip & $20(\% 87)$ & $4(\% 50)$ & $24(\% 77)$ \\
\hline Papiller tip & $1(\% 4)$ & $2(\% 25)$ & $3(\% 11)$ \\
\hline Kromofob tip & $1(\% 4)$ & - & $1(\% 2)$ \\
\hline Ürotelyal tip & $1(\% 4)$ & - & $1(\% 2)$ \\
\hline Diğerleri & - & $2(\% 25)$ & $2(\% 8)$ \\
\hline Sarkomatoid patern & 4 & 1 & 5 \\
\hline \multicolumn{4}{|l|}{ Patolojik evre } \\
\hline $\mathrm{pT} 2 \mathrm{a}$ & $15(\% 66)$ & - & $15(\% 48)$ \\
\hline $\mathrm{pT} 2 \mathrm{~b}$ & - & $4(\% 50)$ & $4(\% 14)$ \\
\hline pT3 & $8(\% 34)$ & $4(\% 50)$ & $12(\% 38)$ \\
\hline Perinefritik invazyon & $5(\% 21)$ & $2(\% 25)$ & $7(\% 21)$ \\
\hline Renal ven invazyonu & $3(\% 13)$ & $2(\% 25)$ & $5(\% 17)$ \\
\hline \multicolumn{4}{|l|}{ Fuhrman derece } \\
\hline 2 & $8(\% 35)$ & - & $8(\% 26)$ \\
\hline 3 & $11(\% 48)$ & $5(\% 62)$ & $16(\% 51)$ \\
\hline 4 & $4(\% 17)$ & $3(\% 38)$ & $7(\% 23)$ \\
\hline
\end{tabular}

\section{Tartışma}

Böbrek tümörlerinin tedavisinde tümör boyutu en önemli prognostik faktörlerden biridir. Küçük kitlelerde minimal invazif yöntemler tercih edilmekle birlikte tümör boyutu büyüdükçe daha radikal yaklaşımlar kullanılmaktadır. Böbrek tümörlerinin cerrahisinde ana amaç tümörlü dokuların tamamen çıkarılmasıdır. $\mathrm{Bu}$ nedenle büyük renal kitlelerde ilk zamanlar radikal nefrektomi, teknolojinin ve görüntüleme yöntemlerinin ilerlemesi ile nefron koruyucu yaklaşımlar ve tecrübeli cerrahların yetişmesiyle laparoskopik radikal ve laparoskopik parsiyel nefrektomi uygulanmıştır (6). Bu ameliyat gruplarının birbirleriyle perioperatif ve onkolojik sonuçlarını karşılaştıran pek çok çalışma bulunmaktadır $(9,10)$. Bizim çalışmamızda tümör boyutu $7 \mathrm{~cm}$ ile $10 \mathrm{~cm}$ arasındaki grupla, $10 \mathrm{~cm}$ 'den büyük boyuta sahip grup perioperatif özellikleri ve onkolojik sonuçlarına göre karşılaştırılmıştır. Çalışmada T2b grubunda hasta say1s1 az olmas1 nedeni ile istatistiksel analizler anlamsız çıkmış bu yüzden analiz yapılmamıştır. Her 2 grubun yaş ortalaması benzer bulunmuş. Histolojik alt tiplere bakıldığında T2a grubunda \%13'lük şeffaf tipte olmayan malignite gözlenirken bu oran $\mathrm{T} 2 \mathrm{~b}$ grubunda \%50'lere çıkmaktadır. $\mathrm{Bu}$ sonuç tümör boyutu artışının şeffaf hücreli dış1 histolojik alt tip patolojisine sahip olabileceği yorumunu yaptırmaktadır. Literatür incelendiğinde benzer sonuçlara ulaşılmıştır. 
Özellikle $10 \mathrm{~cm}$ 'den büyük renal tümörlerde kromofob ve papiller gibi varyantların daha sik gözlendiği rapor edilmiş, $10 \mathrm{~cm}$ altındaki kitlelerde ise $\% 90$ civarında şeffaf hücreli tip gözlendiği bildirilmiştir $(8,11)$.

Çalışmaların büyük kısmında tümör boyutunun artışı ile Fuhrman derecesinin de $\operatorname{arttığ}_{1}$ ve bunun tümörün biyolojik agresifliğinden kaynaklandığı belirtilmektedir. Rothman ve ark. SEER analizinde 19,932 olgu incelenmiş ve $4 \mathrm{~cm}$ 'den küçük kitlelerin $\% 85^{\prime} \mathrm{i}$, $7 \mathrm{~cm}$ 'den büyük kitlelerin ise \%70'inde düşük dereceler gözlenmiştir (11). Bu oran bazı çalışmalarda $7 \mathrm{~cm}$ 'den büyük tümörler için \%33-48 seviyelerine kadar inmektedir (12). Bu sonuçlar ile büyük tümörlü hastaların 5 yıllık sağkalımları oldukça düşmüştür $(8,13)$. Mayo klinikten 2003 yılında yapilan bir analizde tümör boyutunun her $1 \mathrm{~cm}$ artışında \%32'lik yüksek derece artışı olduğu bildirilmiş ancak bu çalışma sadece şeffaf hücreli tiplerde yapılmıştır (14). Bu oranı \%13 olarak veren yazarlarda mevcuttur (11). Çalışmamızda da benzer olarak $10 \mathrm{~cm}$ üzerindeki kitlelerde daha yüksek Fuhrman dereceleri gözlenmiştir.

Onkolojik sonuçlar açısından gruplar karşılaştırıldığında $10 \mathrm{~cm}$ üzerindeki olgularda daha sık rekürrens olduğu görülmüştür. Patolojik evre atlamasının rekürrens gelişiminde önemli belirleyici bir faktör olduğu bilinmektedir. Çalışmamızda T2b grupta \%50 düzeyinde evre atlaması olmuştur. Literatüre baktığımızda yine Mayo klinikten 2005 yılında yapılan bir çalışmada perinefritik invazyon ve renal ven invazyonu gelişerek evre atlayan olgularda rekürrenssiz sağkalım ve kansere bağlı sağ kalımda ciddi derecede düşme görüldügü belirtilmiştir (15). Perinefritik invazyon ve renal ven invazyonunun rekürrenste önemli bir belirteç olduğu pek çok çalışmada doğrulanmış ve sağkalıma etkisi belirlenmiş̧tir (8). Novara ve ark. yaptığ 1 çalışmada T2a ve T2b olgular karşılaştırılmış ve kanser spesifik sağ kalımda belirgin fark bulunmamıştır ancak rekürrenste yüksek derece varlığı, şeffaf hücreli varyant varlığı, renal ven invazyonu ve perinefritik invazyon varlığının etkili olduğu gösterilmiştir (16).

Çalışmamızda bazı limitasyonları bulunmaktadır. Özellikle $10 \mathrm{~cm}$ üzerindeki olgu sayısının yetersiz olması nedeniyle istatistiksel analiz sonuçları anlamsız bulunmuş ve çalışmada belirtilmemiştir. Çalışmadaki tüm olgulara açık radikal nefrektomi uygulanmış ve merkezimizde laparoskopik radikal nefrektomi de yeterli tecrübe bulunmadığı için karşılaştırılma yapılamamıştır. Retrospektif olması ve olguların bir kısmı ile iletişimin kurulamaması nedeniyle sağ kalım analizi yapılamamıştır.

\section{Sonuç}

Tümör boyutu büyük olan renal kitlelerde açık radikal nefrektomi güvenle yapılabilmektedir. Tümör boyutunu artması ile tümör derecesinde artış ve şeffaf hücreli olmayan histolojik alt tiplerde artış görülmekte bu da rekürrenste artışa yol açmaktadır. Renal ven invazyonu ve perinefritik invazyon varlığı rekürrenste önemli bir prognostik faktördür.

\section{Çıkar çatışması: Yok}

\section{Referanslar}

1. Rendon RA, Kapoor A, Breau R et al. Surgical management of renal cell carcinoma: Canadian Kidney Cancer Forum Consensus. Can UrolAssoc J. 2014 May-Jun; 8(5-6): E398-E412. Published online 2014 June 19. doi: 10.5489/cuaj.1894

2. Lipworth L, Tarone RE, Mc Laughlin JK. The epidemiology of renal cell carcinoma. J Urol. 2006 Dec;176(6 Pt 1):2353-8. Review

3. Klatte T, Patard JJ, de Martino M et al. Tumor size does not predict risk of metastatic disease or prognosis of small renal cell carcinomas. J Urol 2008;179(5):1719-26.

doi: 10.1016/j.juro.2008.01.018. Epub 2008 Mar 17

4. Jeffery NN, Douek N, Guo DY, Patel MI. Discrepancy between radiological and pathological size of renal masses. BMC Urol. 2011;11:2. doi: 10.1186/1471-2490-11-2

5. Ljungberg B, Bensalah K, Bex A et al. Guidelines on renal cell carcinoma. European Association of Urology 2015

6. Dağgülli $\mathrm{M}$, Utanğaç $\mathrm{MM}$, Bozkurt $\mathrm{Y}$ ve ark. Laparoskopik radikal nefrektomi deneyimlerimiz. Dicle Tip Dergisi 2014;41:732-737

7. Wells S. Successful removal of two solid circum renal tumors. BrMed J. 1884;1:758

8. Pierorazio PM, Hyams ES, Lin BM, Mullins JK, Allaf ME. Laparoscopic radical nephrectomy for large masses: critical assesment of perioperative and oncological outcomes of stage T2a and T2b tumors. Urology. 2012 Mar;79(3):570-5doi: 10.1016/j.urology.2011.10.065.

9. Portis AJ, Yan Y, Landman J et al. Long-term follow up after laparoscopic radical nephrectomy. JUrol. 2002 Mar;167(3):1257-62

10. Dunn MD, Portis AJ, Shalhav AL et al. Laparoscopic versus open radical nephrectomy: a 9-year experience. J Urol. 2000 Oct;164(4):1153-9 
11. Rothman J, Egleston B, Wong YN, Iffrig K, Lebovitch S, Uzzo RG. Histopathological characteristics of localized renal cell carcinoma correlate with tumor size: a SEER analysis. J Urol. 2009 Jan;181(1):29-33; discussion33-4. doi: 10.1016/j.juro.2008.09.009. Epub 2008 Nov 13

12. Schlomer B, Figenshau RS, Yan Y, Venkatesh R, Bhayani SB. Pathological features of renal neoplasms classified by size and symptomatology. J Urol. 2006 Oct;176(4 Pt 1):1317-20; discussion 1320

13. Tabibi A, Parvin M, Abdi H, Bashtar R, Zamani N, Abadpour B. Correlation between size of renal cell carcinoma and its grade, stage, and histological subtype. Urol J. 2007 Winter;4(1):10-3
14. Frank I, Blute ML, Cheville JC, Lohse CM, Weaver AL, Zincke H. Solid renal tumors: an analysis of pathological features related to tumor size. J Urol. 2003 Dec;170(6 Pt 1):2217-20

15. Thompson RH, Cheville JC, Lohse CM et al. Reclassification of patientswith pT3 and pT4 renal cell carcinoma improves prognostic accuracy. Cancer. 2005 Jul 1;104(1):53-60

16. Novara G, Ficarra V, Antonelli A et al; SATURN Project-LUNA Foundation. Validation of the 2009 TNM version in a large multi-institutional cohort of patients treated for renal cell carcinoma: are further improvements needed? Eur Urol. 2010 Oct;58(4):588-95 